\title{
Pengaruh Penggunaan Slag Nikel Pada Kuat Tekan dan Kuat Lentur Beton Geopolimer
}

\section{Effect of Using Nickel Slag on the Compressive an Flexural Strenght of Geopolymer Concrete}

\author{
Hermana Kaselle ${ }^{1 a}$, Raynaldo Bunga Allo ${ }^{2 b}$ \\ ${ }^{1}$ Jurusan Teknik Sipil Politeknik Negeri Ujung Pandang - Makassar \\ ${ }^{2}$ Jurusan Teknik Sipil Universitas Kristen Indonesia Paulus - Makassar
}

Korespondensi : ${ }^{\text {a) }}$ h.kaselle@poliupg.ac.id, ${ }^{\text {b) }}$ raynaldoallo@gmail.com

\begin{abstract}
Abstrak
Penelitan ini bertujuan untuk mengetahui kekuatan tekan lentur beton geopolimer dengan slag nikel sebagai pengganti agregat halus. Benda uji kuat tekan dengan silinder $10 \times 20 \mathrm{~cm}$ dan uji kuat lentur dengan balok $60 \times 15 \times 15 \mathrm{~cm}$. Pembuatan benda uji dilakukan dengan trial and error serta proses perawatan dilakukan dengan metode perawatan suhu ruang (ambient curing). Pengujian tekan beton (SNI 1974-2011) dilakukan pada umur 7 dan 28 hari, sedangkan uji lentur balok (SNI 4431-2011) pada umur 28 hari. Hasil penelitian diperoleh nilai kuat tekan beton geopolimer yang menggunakan slag nikel pada umur 7 dan 28 hari sebesar 17,942 MPa dan 21, $738 \mathrm{Mpa}$, sedangkan beton kontrol diperoleh kuat tekan berturut-turut sebesar $9,960 \mathrm{MPa}$ dan 16,643 MPa. Peningkatan kuat tekan dengan penggunaan slag nikel sebesar 21,157\%. Nilai kuat lentur rata-rata beton geopolimer yang menggunakan slag nikel 3,928 MPa, sedangkan balok kontrol sebesar 3,324 MPa. Peningkatan nilai kuat lentur beton dengan penggunaan slag nikel sebagai agregat halus sebesar 18,182\% .
\end{abstract}

Kata kunci: Beton Geopolimer, Slag Nikel, Kuat Tekan, Kuat Lentur

\section{PENDAHULUAN}

Beton polimer adalah beton yang menggunakan bahan polimer sebagai pengikatnya menggantikan semen portland. Polimer adalah rantai berulang dari atom yang panjang, terbentuk dari pengikat yang berupa molekul identik yang disebut monomer. Salah satu contohnya ialah ikatan Si-O-Al-O sehingga bahan yang digunakan harus mengandung banyak Aluminium (Al) dan Silikon (Si) yang bisa ditemukan di tanah liat, kaolinit, silica fume, dan Fly Ash. Dalam penelitian ini digunakan ikatan antara Fly Ash dan Alkalin. Fly Ash merupakan sisa mineral dalam butir halus yang dihasilkan dari pembakaran batu bara yang mengandung silicon oksida $\left(\mathrm{SiO}_{2}\right)$, Aluminium Oksida $\left(\mathrm{Al}_{2} \mathrm{O}_{3}\right)$, dan besi oksida $\left(\mathrm{Fe}_{2} \mathrm{O}_{3}\right)$. Cairan alkalin yang merupakan campuran Sodium
Hidroksida $(\mathrm{NaOH})$ dan Sodium silikat $\left(\mathrm{Na}_{2} \mathrm{SiO}_{3}\right)$. Karena banyaknya kandungan material geologi dalam ikatan polimerisasi beton ini, maka beton polimer jenis ini juga biasa disebut dengan beton geopolymer berbasis Fly Ash. Beton geopolimer memberikan keuntungan seperti kekuatan awal yang tinggi, rangkak yang rendah, memiliki ketahanan yang baik terhadap benturan, sulfat, korosi, bahan yang bersifat asam, api dan reaksi alkali-agregat yang tidak membahayakan (Rangan, 2008).

Slag merupakan hasil sampingan dari industri logam setelah dipisahkan dari biji mentahnya. Slag merupakan limbah B3 yang dapat mencemari lingkungan. Dan karena jumlahnya yang banyak dan tidak dimanfaatkan, Slag nikel dapat 
mengancam kesehatan dan ekosistem lingkungan.

Beton polimer merupakan jenis beton yang tidak mengandung semen sama sekali sehingga ramah terhadap lingkungan. Hal ini dikarenakan dalam produksi semen menghasilkan emisi gas $\mathrm{CO} 2$ yang besarnya sebanding dengan jumlah semen yang diproduksi (Davidovits, 1999).

Penelitian ini bertujuan untuk mengetahui nilai kuat tekan dan kuat lentur beton polimer dengan menggunakan slag nikel sebagai agregat halus.

\section{TINJAUAN PUSTAKA}

\section{Material pembuat beton geopolimer}

1) Agregat Kasar

Menurut ASTM C33 agregat kasar adalah agregat yang memiliki ukuran butir lebih dari 4,75 $\mathrm{mm}$. Sifat agregat kasar mempengaruhi kekuatan akhir beton keras dan daya tahannya terhadap disintegrasi beton, cuaca, dan efek-efek perusak lainnya. Agregat kasar harus bersih dari bahan-bahan organik (Mulyono, 2004).

2) Agregat Halus (Slag Nikel)

Agregat halus secara umum merupakan agregat yang memiliki ukuran butiran lebih kecil dari 4,76 $\mathrm{mm}$ dan lebih besar dari $0,075 \mathrm{~mm}$. Dalam penelitian ini menggunakan Slag nikel sebagai pengganti agregat halus. Slag merupakan hasil sampingan dari industri logam setelah dipisahkan dari biji mentahnya. Slag nikel merupakan limbah buangan dari industri pengolahan nikel membentuk liquid panas yang kemudian mengalami pendinginan sehingga membentuk batuan alam yang terdiri dari Slag padat dan Slag yang berpori.
Beberapa penelitian tentang penggunaan Slag nikel sebagai agregat pada beton mutu tinggi. menunjukkan peningkatan kekuatan pada beton baik dengan menggunakan Slag nikel sebagai agregat kasar dan halus maupun hanya sebagai agregat kasar mempunyai kekuatan tekan, tarik, modulus elastisitas, dan berat volume lebih tinggi, disamping susut yang relatif kecil dari beton normal. Adapun keuntungan penggunaan limbah padat (Slag) dalam campuran beton adalah sebagai berikut:

a. Mempertinggi kekuatan tekan beton

b. Menaikkan ratio antara kelenturan dan kuat tekan beton

c. Mempertinggi ketahanan terhadap sulfat dalam air laut

d. Mengurangi panas hidrasi dan menurunkan suhu

e. Memperbaiki penyelesaian akhir dan memberi warna cerah pada beton

f. Mengurangi porositas dan serangan klorida

3) Fly Ash

Fly Ash merupakan sisa mineral dalam butir halus yang dihasilkan dari pembakaran batu bara yang mengandung banyak silikon oksida (SiO2), Aluminium Oksida (Al2O3), dan besi oksida (Fe2O3). Fly ash dapat dibedakan menjadi tiga, yaitu abu terbang yang normal yang dihasilkan dari pembakaran batubara antrasit atau batu bara bitomius (kelas F), abu terbang yang dihasilkan dari batu bara jenis lignite atau subbitumeus (kelas C), dan abu terbang yang dihasilkan dari hasil kalsinasi pozolan alam seperti tanah diatonice, shole, tuft, batu apung (kelas N). Material abu terbang dikategorikan dalam material 
(e)ISSN 2775-0213

Journal of Applied Civil and Environmental Engineering - Vol. 1, No. 2, Oktober 2021

"pozzolon" yakni bahan yang mengandung senyawa Silica dan Alumina yang tidak mempunyai sifat seperti semen, akan tetapi dengan bentuknya yang halus dan jika senyawa-senyawa tersebut bereaksi secara kimia dengan cairan alkalin pada temperatur tertentu dapat membentuk material campuran yang memiliki sifat seperti semen. Material pozzolan ini dapat mengurangi pemuaian akibat proses reaksi alkalin dan agregat sehingga dapat mengurangi retak-retak pada beton.

Berdasarkan ASTM C 618 fly ash diklasifikasikan atas 2 kelas berdasarkan komposisi kimianya yaitu fly ash tipe F dan C. Dimana fly ash tipe $\mathrm{F}$ merupakan hasil dari batu bara bitumen dengan kandungan kalsium yang rendah kurang dari $10 \%$ CaO. Sedangkan tipe C merupakan hasil dari batu bara subbitumen dengan kandungan kalsium yang tinggi di atas $20 \% \mathrm{CaO}$. Dibandingkan dengan fly ash tipe F, fly ash tipe $\mathrm{C}$ lebih mampu meningkatkan mutu kuat tekan beton karena kandungan kalsium yang tinggi dan mampu mengurangi kadar air karena memiliki bentuk partikel yang bulat dan ukuran yang kecil sehingga mampu mengisi ronggarongga kecil yang kosong.

\section{4) Alkali}

Logam Alkali adalah golongan dalam tabel periodik yang berisi unsur - unsur litium ( $\mathrm{Li}$ ), natrium $(\mathrm{Na})$, kalium $(\mathrm{K})$, rubidium $(\mathrm{Rb})$, sesium (Cs) dan fransium (Fr) (Wikipedia). Penggunaan alkali sebagai aktivator dalam pembuatan polimer baik pada polimer mortar maupun polimer beton memiliki peranan yang sangat penting sebagai salah satu bahan pengikat unsur alumunium dan unsur silikat yang terkandung dalam abu terbang sehingga terbentuk suatu ikatan polimerisasi dan mempercepat reaksi yang terjadi antara abu terbang dan unsur-unsur tersebut. Semakin tinggi konsentrasi aktivator maka kuat tekan mortar polimer yang dapat dicapai umumnya juga semakin meningkat. Hal ini dikarenakan semakin tinggi konsentrasi aktivator maka jumlah mol yang terdapat di dalamnya semakin banyak sehingga reaksi polimerisasi semakin sempurna.

Sodium Hidroksida $(\mathrm{NaOH})$ dan Sodium silikat (Na2SiO3) dapat digunakan sebagai alkali activator beton polimer (Hardjito, 2005). Sodium silikat (Na2SiO3) dapat berfungsi untuk mempercepat reaksi polimerisasi yang terjadi pada beton polimer sedangkan sodium hidroksida $(\mathrm{NaOH})$ berfungsi untuk mereaksikan unsur $\mathrm{Al}$ dan $\mathrm{Si}$ yang terkandung dalam abu terbang sehingga dapat menghasilkan ikatan polimer yang kuat. Dibandingkan dengan semen dan air yang menggunakan proses hidrasi sehingga menciptakan pori-pori lebih banyak dalam proses pelepasan air.

5) Aquades

Aquades dalam beton geopolimer sebagai bahan pengikat dalam pencairan larutan molaritas $\mathrm{NaOH}$. Semakin banyak aquades yang ditambahkan pada $\mathrm{NaOH}$, semakin rendah pula molaritas yang dihasilkan dan akan membuat beton kurang mengikat terhadap fly ash.

\section{Karakteristik Beton Polimer}

\section{Kuat Tekan}


Menurut SNI 1974-2011, pengujian kuat tekan merupakan pemberian beban monoton secara terus menerus dengan laju yang konstan pada benda uji di antara dua batang pembebanan yang akan menciptakan tegangan tekan. Pada pengujian kuat tekan posisi benda uji yang berbentuk silinder pada saat dibebani yaitu dalam keadaan berdiri/tegak. Tegangan tekan yang dialami benda uji lama kelamaan akan menyebabkan benda uji runtuh/hancur. Sehingga, kuat tekan adalah tegangan tekan pada pembebanan maksimum yang menyebabkan benda uji mengalami keruntuhan

Nilai kuat tekan beton dapat dihitung dengan persamaan sebagai berikut:

$$
\begin{gathered}
f_{c}^{\prime}=\frac{P}{a} \\
\text { Dimana: } \\
\mathrm{f}^{\prime}{ }_{\mathrm{c}} \quad=\text { Kuat tekan beton }(\mathrm{Mpa}) \\
\mathrm{P} \quad=\text { Beban maksimum }(\mathrm{N}) \\
\mathrm{A} \quad=\text { Luas penampang }\left(\mathrm{mm}^{2}\right)
\end{gathered}
$$

\section{Kuat Lentur}

Kuat lentur beton adalah kemampuan balok beton untuk menahan gaya dengan arah tegak lurus sumbu yang diberikan padanya sampai balok beton patah dan dinyatakan dalam Mega Pascal (MPa). Tegangan lentur ini dikenal dengan istilah Modulus of Rupture (SNI 4431-2011).

Rumus-rumus perhitungan yang digunakan dalam pengujian lentur adalah:

1. Untuk pengujian dimana bidang patah terletak di daerah pusat (daerah 1/3 jarak titik perletakan bagian tengah), maka kuat lentur Beton dihitung persamaan sebagai berikut:

$$
\sigma_{l}=\frac{P \cdot L}{b \cdot h^{2}}
$$

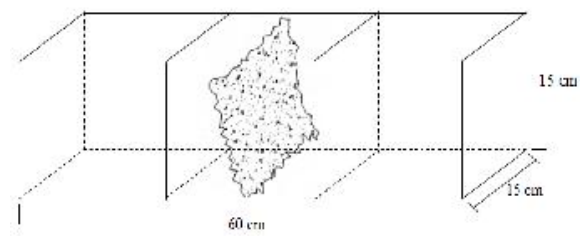

Gambar 1. Daerah patah pada 1/3 bentang tengah balok

2. Untuk Pengujian dimana patahnya benda uji ada di luar pusat (daerah $1 / 3$ jarak titik perletakan bagian tengah), dan jarak antara titik pusat dan titik patah kurang dari $5 \%$ dari jarak titik antar perletakan maka kuat lentur beton dihitung dengan persamaan sebagai berikut:

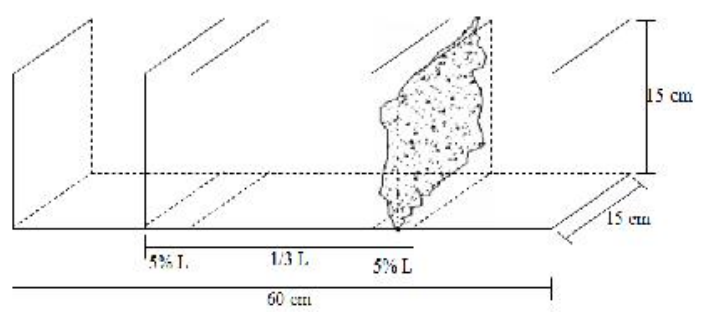

Gambar 2. Daerah patah di luar $1 / 3$ bentang tengah balok dan garis patah pada $<5 \%$ dari panjang bentang

$\sigma_{2}=\frac{P_{n} a}{b \cdot h^{2}}$

Dimana:

$\sigma_{l} \quad$ : Kuat lentur benda uji (MPa)

$\mathrm{P}$ : Beban tertinggi yang terbaca pada mesin uji kuat lentur beton

L : Jarak bentang antara dua garis perletakan $(\mathrm{cm})$

b : Lebar penampang lintang patah arah horizontal $(\mathrm{cm})$

$\mathrm{h} \quad$ : Lebar penampang lintang patah arah vertical $(\mathrm{cm})$

a : Jarak rata-rata antara penampang lintang patah dan tumpuan luar yang terdekat, 
(e)ISSN 2775-0213

Journal of Applied Civil and Environmental Engineering - Vol. 1, No. 2, Oktober 2021

diukur pada 4 tempat pada sudut dari bentang $(\mathrm{cm})$

\section{METODE PENELITIAN}

\section{Bahan}

Bahan penelitian ini berupa Agregat kasar berupa batu pecah, Agregat halus berupa pasir dan slag nikel yang berasal dari PT. IMIP Morowali Sulawesi Tengah, Fly Ash Type C dari PT Makassar Tene Sugar Refinery Makassar, Alkali berupa campuran sodium silikat $\left(\mathrm{Na}_{2} \mathrm{SiO}_{3}\right)$ dan sodium hidroksida $(\mathrm{NaOH})$ dengan perbandingan berat 1,5, dan air (aquades).

\section{Identifikasi Benda Uji}

Tabel 1. Identifikasi Benda Uji untuk Pengujian

\begin{tabular}{ccc}
\hline Jenis Pengujian & \multicolumn{2}{c}{$\begin{array}{c}\text { Jumlah benda } \\
\text { uji }\end{array}$} \\
\cline { 2 - 3 } & 7 hari & $\begin{array}{c}28 \\
\text { hari }\end{array}$ \\
\hline $\begin{array}{c}\text { Kuat Tekan Beton } \\
\text { Polimer (PCS) } \\
\text { Kuat Lentur Beton } \\
\text { Polimer (PFS) }\end{array}$ & 5 & 5 \\
$\begin{array}{c}\text { Kuat Tekan Beton } \\
\text { Polimer (PCN) } \\
\text { Kuat Lentur Beton } \\
\text { Normal (PFN) }\end{array}$ & 5 & 5 \\
\hline Total & 10 & 20 \\
\hline
\end{tabular}

Dalam penelitian ini benda uji yang digunakan untuk pengujian kuat tekan beton adalah benda uji berbentuk silinder dengan diameter $10 \mathrm{~cm}$ dan tinggi $20 \mathrm{~cm}$. Sedangkan untuk pengujian kuat lentur digunakan benda uji berbentuk balok dengan panjang $60 \times 15 \times 15 \mathrm{~cm}$.

\section{Pembuatan Benda Uji}

Langkah-langkah pembuatan benda uji adalah sebagai berikut:

a. Siapkan alat-alat yang akan digunakan dalam keadaan bersih dan bahan-bahan penelitian b. Timbang material agregat kasar, slag nikel dan fly ash sesuai dengan perhitugan komposisi yang telah dihitung

c. Siapkan cairan alkalin yakni Sodium Silikat dan Sodium Hidroksida yang telah dicampur sehari sebelum mixing.

d. Setelah semua bahan siap, fly ash, slag nikel dan agergat kasar kemudian dimasukkan ke dalam mixer (molen) lalu diaduk selama \pm 3 menit

e. Tambahkan cairan alkalin dan air lalu aduk kembali hingga merata

f. Masukkan adukan beton ke dalam cetakan secara bertahap sebanyak 3 lapisan dengan masing-masing lapisan ditumbuk dengan tongkat penumbuk sebanyak 25 kali tiap lapisan

g. Cetakan ditumbuk pada semua sisi hingga gelembung udara dalam beton keluar

h. Benda uji kemudian didiamkan dalam cetakan selama 24 jam

i. Setelah 24 jam benda uji dibuka dari cetakan lalu dicuring dengan Ambient Curing (perawatan suhu ruangan).

\section{Perawatan Benda Uji}

Perawatan benda uji dilakukan dengan Ambient Curing (perawatan suhu ruang) dengan cara membungkus (wrapping) beton selama 4 hari demi mempertahankan suhu beton sebelum dilepaskan dari cetakan. Setelah dibungkus selama 4 hari beton dikeluarkan dari cetakan dan didiamkan dalam suhu ruangan hingga hari pengujian. Perawatan dengan cara ini dilakukan agar proses hidrasi berlangsung secara optimal sehingga mutu beton yang diharapkan dapat tercapai dan tidak terjadi kehilangan kelembaban dengan terlalu cepat yang dapat menyebabkan terjadinya susut yang berlebihan. 


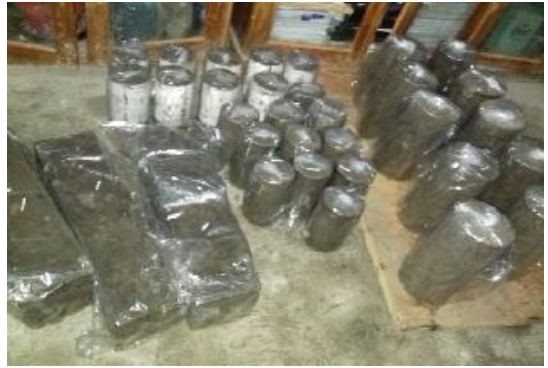

Gambar 3. Perawatan Benda Uji

\section{ANALISIS PENELITIAN}

\section{Kuat Tekan Beton}

Prosedur pengujian dilaksanakan berdasarkan SNI 1974-2011, dimana benda uji diletakkan pada mesin tekan secara sentris. Kekuatan tekan dapat didefinisikan sebagai ketahanan maksimum diukur dari benda uji beton untuk beban aksial.

Hasil pengujian kuat tekan rata-rata dari masing-masing umur beton dapat dilihat pada Tabel 2.

Tabel 2.Hasil Kuat Tekan Rata-Rata

\begin{tabular}{ccc}
\hline $\begin{array}{c}\text { Jenis } \\
\text { Beto } \\
\mathbf{n}\end{array}$ & $\begin{array}{c}\text { Kuat Tekan Rata-Rata } \\
\text { Beton (MPa) }\end{array}$ & \\
\cline { 3 - 3 } & $\mathbf{7 ~ H a r i}$ & $\begin{array}{c}\mathbf{2 8} \\
\text { Hari }\end{array}$ \\
\hline $\begin{array}{c}\text { Beton } \\
\text { PCS }\end{array}$ & 16,643 & 21,738 \\
Beton & 9,960 & 17,942 \\
PCN & & \\
\hline
\end{tabular}

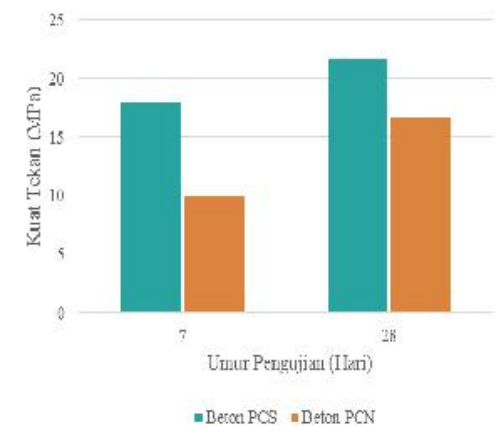

Gambar 1. Hasil Pengujian Kuat Tekan
Berdasarkan pengujian dapat dilihat bahwa beton PCS memiliki kuat tekan yang lebih tinggi dari beton PCN yaitu sebesar 21,738 MPa. Dari hasil tersebut dapat disimpulkan bahwa beton yang menggunakan slag nikel sebagai agregat halus mengalami peningkatan kuat tekan sebesar $21,157 \%$. Nilai kuat tekan yang diperoleh pada umur 7 hari menunjukkan nilai kuat tekan yang cukup besar di usia beton awal, hal ini menunjukkan penggunaan slag nikel pada beton akan memberikan kekuatan awal yang tinggi pada beton geopolimer.

\section{Kuat Lentur Beton}

Prosedur pengujian dilaksanakan berdasarkan SNI 4431-2011, dengan benda uji berbentuk balok dengan ukuran $60 \times 15$ x $15 \mathrm{~cm}$. Benda uji diletakkan pada alat uji lentur dengan dua titik pembebanan.

Berdasarkan Gambar 5, dapat dilihat bahwa beton PFS memiliki kuat lentur yang lebih tinggi dari beton PFN yaitu sebesar 3,928 Mpa. Hasil tersebut menunjukkan bahwa beton yang menggunakan slag nikel sebagai agregat halus mengalami peningkatan kuat lentur sebesar $18,182 \%$.

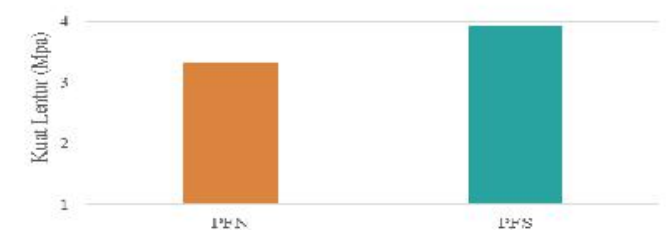

Gambar 5. Hasil Pengujian Kuat Lentur

\section{KESIMPULAN}

Berdasarkan hasil penelitian dan hasil analisis yang telah dilakukan dapat diambil kesimpulan yaitu: 
(e)ISSN 2775-0213

Journal of Applied Civil and Environmental Engineering - Vol. 1, No. 2, Oktober 2021

1. Nilai kuat tekan rata-rata beton polimer yang menggunakan slag nikel sebagai agregat halus bahan campuran beton pada pengujian umur 28 hari sebesar 21,738 $\mathrm{MPa}$, sedangkan kuat tekan beton polimer yang menggunakan pasir sebagai agregat halus pada pengujian umur yang sama sebesar 17,942 MPa. Dari hasil tersebut dapat disimpulkan bahwa beton yang menggunakan slag nikel akan memberikan peningkatan kuat tekan sebesar $21,157 \%$.

2. Nilai kuat lentur rata-rata beton polimer yang menggunakan slag nikel sebagai agregat halus bahan campuran beton sebesar 3,928 $\mathrm{MPa}$, sedangkan kuat lentur beton polimer yang menggunakan pasir sebagai agregat halus sebesar 3,324 MPa. Dari hasil tersebut dapat disimpulkan bahwa penggunaan slag nikel akan memberikan peningkatan kapasitas lentur balok sebesar $18,182 \%$.

\section{DAFTAR PUSTAKA}

Rangan B. V, 2008, Fly Ash-Based Geopolymer Concrete, Curtin University of Technology: Perth, Australia.

Davidovits, J, 1999, Chemistry of Geopolymer System, Terminology. Geopolymer '99 International Conference: Saint-Quentin, France.

Mulyono, Tri, 2004, Teknologi Beton, Yogjakarta.

Hardjito, dkk, 2005, On the Development of Fly ash-Base Geopolymer Concrete. Technical Paper No. 101M52, ACI Material Journal, vol. 101, no. 6.

SNI 1974-2011, Cara Uji Kuat Tekan Beton Dengan Benda Uji Silinder, Standar Nasional Indonesia

SNI 4431-2011, Cara uji kuat lentur beton normal dengan dua titik pembebanan, Standar nasional Indonesia 